\title{
Grounding Religious Toleration: Kant and WolfF on Dogmatic Conflict
}

\author{
- Dino Jakušić -
}

\begin{abstract}
This article examines Paul Guyer's claim that we should attempt to ground the principle of religious freedom on the basis of Kant's arguments for religious liberty. I problematise Guyer's suggestion by investigating a hypothetical 'dogmatic conflict' between a scientifically and a religiously grounded belief. I further suggest that considering Christian Wolff's philosophy might provide us with an approach which shares the benefits that Guyer identifies in Kant, while at the same time avoiding the issues Kant might run into that result from the occurrence of the dogmatic conflict. I start by providing a background to Wolff's philosophy and explaining the notion of the dogmatic conflict. Then I present a potential contemporary case of the dogmatic conflict and try to see how it would be dealt with based on Guyer's proposal. Finally, I consider what a Wolffian solution would look like, arguing that Guyer's project might benefit from considering Wolff.
\end{abstract}

Keywords: Immanuel Kant, Christian Wolff, Paul Guyer, Moses Mendelssohn, dogmas, dogmatic conflict, religious liberty.

Published online: 19 September 2020

\section{Introduction}

In a recent article, Paul Guyer (2018) argued that religious freedom, i.e. the freedom to practice any or no religion, is currently under attack in the West. Guyer does not provide a detailed account in what way or by whom this freedom is under attack, however, a cursory glance at the state of the political discourse in the USA offers plenty of candidates. For example, in 2016, in an interview with ABC News, after his speech at the Republican National Convention, Antonio Sabàto Jr. claimed that the then US president Barack Obama was a Muslim, suggesting that whoever is not a Christian is implicitly treasonous and should be disqualified from holding a public office. When the interviewers pressed him for evidence or any coherent argument for his claim about Obama not being a Christian, the ultimate response he could provide was "it is in my heart" and "I have the right to believe that. And you have the right to go against that..."1

Dino Jakušić

Department of Philosophy

University of Warwick

Coventry, CV4 7AL

United Kingdom

email: dino.jakusic.1@warwick.ac.uk

${ }^{1}$ See McCaskill (2016). 
In order to counter this kind of attacks, Guyer suggests rethinking the philosophical basis for the adoption of the principle of religious freedom. He finds Immanuel Kant's arguments for religious liberty to be a promising ground for this project. Guyer then proceeds by directly comparing Kant's argument for religious liberty with the argument presented by Moses Mendelssohn, and indirectly with arguments he finds in James Madison and John Locke.

In short, Guyer argues that Mendelssohn's, Madison's, Locke's, as well as "much of eighteenth-century thought about religious liberty," is grounded upon religious premises. ${ }^{2}$ Stemming from Locke's Letter Concerning Toleration of 1689, Mendelssohn's and Madison's thoughts on religious toleration are based on two fundamental premises: i) a non-religious "assumption that inner convictions cannot be modified by the outward tools available to the state" and ii) a "Protestant conviction that only freely adopted convictions are acceptable to God, and that God has given everyone the authority to form his own religious convictions, not having delegated this to anyone, let alone to civil authorities." 3 For Mendelssohn, therefore, neither the state nor indeed the church can apply coercive means to influence religious conviction because this is both impossible (according to the non-religious premise) and contrary to the spirit of (Protestant) religion (according to the religious premise). The only thing the state can demand is an outward compliance with its laws, ${ }^{4}$ and it can only "regulate external actions of churches and their members if these threaten the civil order." ${ }^{5}$

In contrast to Mendelssohn and others, Guyer continues, Kant provides us with "the most extensive religious liberty consistent with public peace while resting on no religious premises at all ... [but] only on the innate right to freedom ..." ${ }^{\prime 6}$ According to Guyer, Kant's formulation of the principle underpinning religious liberty is more extensive than the others' because it arises as a corollary of a more general moral demand to promote freedom, ${ }^{7}$ rather than being posited as a special principle applicable only to religion. It is also independent from either of the two previous premises, being itself grounded on the "Universal Principle of Right," i.e., the fundamental principle of morality that requires of us not to hinder the freedom of any person, unless that person's exercise of freedom were to hinder the freedom of another. ${ }^{8}$ From this it follows, Guyer argues, that one is free to do, believe, say, or act in any way that does not directly diminish the freedom of others. Hence any religious belief or action, or absence of it, must be tolerated and defended by the state unless it directly diminishes the freedom of others. ${ }^{9}$

In this article, it is not my intention to criticise Guyer's reading of Kant and Mendelssohn, or of other Enlightenment arguments for religious liberty. Moreover, I will not

\footnotetext{
${ }^{2}$ Guyer (2018): 311. Or at least, Mendelssohn and the "Anglo-American" tradition are, if not most of the Enlightenment thought in general; see ibidem: 322.

${ }^{3}$ Ibidem: 313. Guyer argues that there is no tension between Mendelssohn being Jewish and this premise being Protestant. See ibidem: 317 .

${ }_{4}$ Ibidem: 318.

${ }^{5}$ Ibidem: 321.

${ }^{6}$ Ibidem: 328 .

7 See ibidem: $322,323,326$.

8 Ibidem: 322-324.

9 Ibidem: 325-326.
} 
dispute Guyer's general claims, e.g. that religious liberty is in crisis, or that it might be beneficial to utilise Kant's philosophy to discuss the principles underpinning religious freedom and toleration today. What I wonder, however, is whether adopting Kant's principle of religious freedom as Guyer presents it, i.e. as a particular model of negative liberty, helps us to address the attacks on religious freedom by the likes of Sabàto.

Certainly, inane statements by one US actor cannot on their own prove that this type of religious intolerance is the main danger facing religious toleration today, but one thing Sabàto's position can be seen as illustrative of is the tendency of public figures to provide statements of fact, backed only by an appeal to their sincere belief in the claim stated and their right to hold and profess such a belief. I would certainly not argue that the state should forbid or police people for believing or publicly stating groundless nonsense, but the fact that some important public personas feel comfortable to openly justify outrageous positions on such private and individualistic grounds speaks to a worrying move away from common standards of what counts as proof or justification of belief. ${ }^{10}$

While it would be ridiculous to state that Guyer's negative formulation of the principle of religious freedom would necessarily lead to the proliferation of this kind of culture of belief, freedom-grounding arguments based on negative liberty seem to be less effective in countering it. If we were to focus only on the rights of individuals to hold or profess beliefs freely, we might miss an opportunity to develop a principle that would allow us to go a step further and find ways of establishing a dialogue between conflicting beliefs. Therefore, this article has two general goals. Firstly, if we wish to find a new grounding for religious freedom and toleration, one which would be based on general principles and not depend on any religious premises, and if we are looking for this in $18^{\text {th }}$-century Europe, I want to show that there are more options we can choose from than just Kant. Secondly, looking beyond Kant and the catalogue of thinkers Guyer engages with, I want to sketch an alternative model allowing us to think about the issue from the perspective of positive liberty, grounded specifically in an attempt to find peace and reconciliation between differing positions on the basis of universally shared methods and criteria for finding the truth. I find the possibility to formulate this alternative principle in the philosophy of Christian Wolff, and will present it through the context of what I call 'dogmatic conflict'.

In what follows, I introduce the terms 'dogma' and 'dogmatic conflict' from the perspective of Wolff's philosophy. I then apply the conception of 'dogmatic conflict' to a hypothetical issue arising from a recent legislative decision in the US. On this basis, I argue that Guyer's formulation of the principle of religious freedom might yield undesirable results in certain contexts in which the discussion of religious liberty can occur today. Then I present a possible Kantian response to this issue, going beyond Guyer, and argue that it might also be unsatisfactory due to Kant's requirement that beliefs based on religious grounds exemplify beliefs of practical, rather than theoretical, reason. Finally, I present a framework through which Christian Wolff might address dogmatic conflicts and religious toleration, arguing that several aspects Guyer identifies in Kant's account

\footnotetext{
${ }^{10}$ Many will be familiar with the famous Sky News interview with Michael Gove from the $3^{\text {rd }}$ of June 2016, where he stated that "the people in [the UK] have had enough of experts" - a statement that he justified by calling it "a faith ... in British people to make the right decision."
} 
of toleration are already present in Wolff, and that the Wolffian position regarding dogmatic conflicts might be seen as more relevant than the Kantian position to some of the issues facing us today.

\section{On dogmas}

Today, the terms 'dogma' or 'dogmatic' are most widely used in reference to a belief held in an unwavering, biased, or unreflective way. Alternatively, they can be used in reference to a set of (unquestioned) beliefs that a religious group might subscribe to. In more academic contexts, we may speak of dogmatic theology, i.e. a discussion of theoretical doctrines officially held by a church. Some will also be familiar with 'dogmatism', which Kant identifies as a theoretical framework exemplified by Wolff and Baumgarten, which his own 'criticism' aims to overcome. ${ }^{11}$ It is in this context of Wolffian philosophy that I will be using the terms 'dogma' and 'dogmatic conflict'.

In Wolff's Latin philosophy, 'dogma' is a term that designates universal truths. Wolff dedicates the first chapter of the third section of his Latin Logic, first published in 1728 , to discussing the utility of logic in differentiating between types of books. Books, according to Wolff, can be distinguished into those which "survey facts [recensentur facta] about nature or people" and those which "put forth dogmas, or universal truths." 12 The former are called 'historical' [historici], while the latter are called 'dogmatic'. ${ }^{13}$ If we look back at the tenth chapter of his German Logic of 1713, which covers the question of how logic is to be used in judging books, we can see that not much has changed between the earlier German and the later Latin text. In the German Logic, we are told that "texts either treat of histories [Geschichten] or of certain dogmas [gewisse Lehren]. The first, usually called historical, report either of what takes place in nature, or what takes place among people."14

${ }^{11}$ See KrV B xxxv. References to Kant will be given by stating the numbers of the Berlin Academy edition, except in the case of the Critique of Pure Reason, where references to page numbers in the original A and B editions are provided. It might be important to point out that Kant does not object to the dogmatic procedure (an a priori proof from well-established principles) which he sees Wolff's method as exemplifying, but rather to dogmatism, which is the employment of the dogmatic procedure without the prior critique of the capacities of this procedure. For more detail see Gava (2018).

12 “... proponuntur dogmata, seu veritates universales." Wolff (1735): \$\$743, 750. Hereafter: LL. References to Wolff are provided through section numbers of the relevant work, with asterisks $\left(^{*}\right)$ referring to Wolff's elaborations of the section in question. When necessary, I also include chapter numbers. All translations from Wolff are mine, unless the bibliographical entry has been provided for the translation.

${ }^{13}$ LL: $\$ \$ 744,750$.

${ }^{14}$ Wolff (1713): c. 10, §1. Hereafter: DL. In the German Logic Wolff does not give the name 'dogmatisch' or any name at all to the second class of books. Another difference is that in the Latin Logic, Wolff also separates dogmatic books into historical and scientific dogmatic books, the first of which only provide us with a survey of dogmas, while the second demonstrate or test dogmas (LL: §751). Modern examples of the two could be a school textbook and a scientific article. Using the term 'historical' to designate the cataloguing of facts is connected to Wolff's distinction between three kinds of cognition - historical, mathematical, and philosophical - which correspond, respectively, to cognising a certain fact, a certain numerical relation between facts, and a reason for which a fact is or obtains. Wolff will call any cognition 'historical' if it results from accepting something as true on the authority of another. For this distinction see the first chapter of Wolff's Discursus præliminaris (hereafter: DP) that was originally written as an introductory segment to the Latin Logic. 
This does not tell us much on its own, and we should analyse Wolff's texts more carefully in order to see what dogmas are. The first example of a dogmatic book that Wolff provides us with is Euclid's Elements in which Euclid not only enumerates, but in fact "demonstrates [demonstrat] fundamental dogmas regarding magnitudes and figures." In the same passage, Wolff also adds that his Logica "lays out [proponit] dogmas regarding the directing of the intellect in the cognition of truths." 15 This tells us that dogmas are not exclusive to religious writings or beliefs for Wolff, and that they can be demonstrated or proven. There is therefore nothing 'dogmatic', in the common sense of our time, regarding dogmas. ${ }^{16}$ Dogmas will be found in every philosophical (or scientific) discipline, ${ }^{17}$ and to such an extent that the philosophical (or scientific) method itself is defined by Wolff as "the order which the philosopher ought to use in treating dogmas."18

The example of Euclid's Elements allows us to specify more clearly what dogmas are than the earlier claim that they are 'universal truths'. They are, first and foremost, propositions, and according to Wolff's classification of propositions, they are 'theorems' [theorema; Lehrsätze], or "demonstrative theoretical propositions." ${ }^{19}$ Firstly, this means that they are distinct from 'problems' [problemata; Aufgaben], which are demonstrative practical propositions, ${ }^{20}$ and 'axioms' [axiomata; Grundsätze], which are "indemonstrable theoretical propositions" ${ }^{21}$ or "theoretical propositions drawn from a single definition." 22 Examples of axioms Wolff provides are propositions such as "the whole is greater than its part" and "a square is a rectangular figure." ${ }^{23}$ On the other hand, the first example of a theorem is the Pythagorean proposition that the square of the hypothenuse of a right-angled triangle is equal to the sum of the squares of the other two sides. Similarly, all demonstrated theoretical propositions of Wolff's Logica are examples of theorems. ${ }^{24}$ Axioms, therefore, require no demonstration, and their truthfulness can be derived definitionally, if we properly understand the terms in question. Theorems, however, are not definitionally obvious, since they are derived by "placing together several definitions," 25 and hence require additional demonstration through a proper

\footnotetext{
${ }^{15}$ LL: $§ 750 *$.

${ }^{16}$ In fact, 'historical' books allow for no demonstration and are of use only to scientific novices, while dogmatic ones must always be rigorously demonstrated, similarly to how proofs are demonstrated in mathematics. See DL: c. 10, §22.

${ }^{17}$ LL: $\$ 752$.

${ }^{18}$ DP: $\$ 115$. The concepts of 'order' and 'method' are central in Wolff's philosophy, but I do not have space to develop them in detail here. The most extensive treatment of Wolff's method in English language to date remains C.A. Corr's 1963 thesis. There is also a recent article by Gabriele Gava (2018) who interprets Wolff's method in relation to Kant. For a great recent overview of Wolff's method in German, as well as an account of Wolff's identity between 'scientific', 'philosophical', and 'mathematical' method, see Gómez-Tutor (2018).

${ }^{19}$ LL: §275; DL: c. 3, §14.

${ }^{20}$ LL: $\$ 276 ;$ DL: c. 3, §14.

${ }^{21}$ LL: $\$ 267$.

${ }^{22}$ LL: §267; DL: c. $3, \S 13$.

${ }^{23}$ LL: $\S \S 267^{*}, 268^{*}$.

${ }^{24}$ LL: $\$ 275^{*}$.

${ }^{25}$ DL: c. $3, \S 14$.
} 
method for their truth to be visible. ${ }^{26}$ Due to this minimal definition, theorems and dogmas are present in all sciences, differing only with respect to their object, even though their purest employment is found in mathematics. Similarly, theoretical propositions found in religious texts are likewise theorems, and can be divided in the same way as the scientific ones and can be examined in the same manner. ${ }^{27}$

The final aspect of dogmas that should be pointed out is that while all dogmas might be theorems, not all theorems are dogmas. This is because of another category that Wolff introduces that he names 'philosophical hypothesis'. Philosophical hypotheses are theoretical assumptions that are posited in order to provide a possible explanation for a certain phenomenon, but which lack full demonstration. A philosopher is free to posit hypotheses, derive conclusions from them, and orient investigations around them, but must bear in mind that these demonstrations are grounded on an assumption which remains open to be disproven or confirmed. ${ }^{28}$ Importantly, "[h]ypotheses should not be used as principles in the demonstration of propositions which are admitted into philosophy as dogmas." ${ }^{29}$ Dogmas are supposed to be universal truths and a hypothesis cannot yet claim this status, since the truth of it has not yet been demonstrated. Wolff's examples of hypotheses include the Leibnizian theory of Pre-Established Harmony, which he sees as a hypothesis regarding the relation between mind and body. ${ }^{30}$ Another example Wolff gives is Galileo's hypothesis of 'Earth in motion', the truthfulness of which Galileo was not able to demonstrate, even though he managed to show the utility of adopting it as an assumption for the purpose of calculating celestial motion, and which we are today able to elevate to the status of a scientific dogma. ${ }^{31}$

At this point it might be worth noting that it sounds somewhat strange to use the term 'dogma' today for an established scientific theory. For example, if we hold that the essential component of a scientific theory is Popperian falsifiability, how could a theory be both falsifiable and a dogma at the same time? We should remember, however, that for Wolff dogmas are propositions the truth of which has been demonstrated by the proper method of scientific discovery, not beliefs held uncritically or closed to further revision. While Wolff modelled his method on geometry, there is nothing preventing us from arguing that some other conception of the scientific method, e.g. the one requiring theories to be falsifiable, is necessary for a theory to count as scientific. On the other hand, one may consider referring to scientific theories as 'dogmas' to be not merely strange, but dangerous, since it could be perceived as playing into the hands of those who might try

\footnotetext{
${ }^{26}$ This might remind us of Kant's distinction between analytic and synthetic judgments, however, we need to be careful not to conflate the synthetic and analytic method, which for Wolff is related to the order of presenting scientific dogmas, with the analytic and synthetic judgment that are Kant's invention. For more detail see Gava (2018). For Kant's understanding and critique of Wolff's scientific dogmata as applied to physics, see Frketich (2019). For the critique of Kant's distinction between synthetic and analytic judgments by later Wolffians, especially with regard to metaphysics and mathematics, see Beiser (1987): 194-196.

${ }^{27}$ DL: c. $12, \S 8$.

${ }^{28}$ DP: $\S \S 127-128$.

${ }^{29}$ DP: $\$ 128$.

${ }^{30}$ DP: $\$ 164$.

${ }^{31}$ DP: $\$ 168$.
} 
to undermine established scientific theories by treating them as if they were epistemically equivalent to conflicting religious beliefs. This danger, however, arises only if we identify dogmas with religious beliefs and understand religious beliefs in a particular way, e.g. as beliefs held solely on the grounds of personal faith. This would make it a matter of faith whether one believes that the Earth was once populated by dinosaurs or by talking serpents. But this is not how Wolff understands what either dogmas or religious beliefs are. Therefore, I do not find using the term overly problematic, especially once we are aware that the term 'dogma' in the context of this paper, and in Wolff's philosophy, is not used in its everyday sense. If one finds the term inadequate, it could easily be substituted by the term 'doctrine'.

Dogmas, therefore, are theorems that have either been demonstrated to be true (in the ideal case), or have been accepted as true by a certain community (more likely). Since it is possible for a theorem to be declared a dogma by a community, even though it might not fulfil Wolff's strict demonstrative conditions, this can give rise to what I will call 'dogmatic conflict'.

\section{On dogmatic conflict}

While the phrase 'dogmatic conflict' does not appear explicitly in Wolff's philosophy, by this phrase we can designate an occurrence when two or more mutually contradictory dogmas are discovered, or more precisely, when two inconsistent theoretical propositions are both asserted as having the status of a dogma. While this type of conflict can occur between any number of disciplines, ${ }^{32}$ I will here focus only on the case of conflict between what can be called scientific and religious dogmas.

In his Preliminary Discourse, Wolff provides several examples of what could be construed as this kind of dogmatic conflict. One of these examples, according to Wolff, is an apparent conflict between Leibniz' claim in the Theodicy that our world is the best of all possible worlds, while the Sacred Scripture, Wolff continues, declares all the world to be evil. ${ }^{33}$ Other examples he provides are: a conflict between philosophy and religion arising from the theory of Pre-Established Harmony, as it supposedly requires adopting religiously (and politically) unacceptable doctrine of fatalism; Galileo's conflict with the Roman Curia regarding heliocentrism; an unspecified conflict between philosophers and "certain Fathers of the Church" regarding the roundness of the Earth. ${ }^{34}$

\footnotetext{
${ }^{32}$ Or even within the same discipline, an example of which is the disagreement between Leibniz and Newton regarding the nature of the differential method. See DP: $\$ 158^{*}$.

${ }^{33}$ DP: §158*. Wolff does not provide an explicit reference to the Bible at this point, however, it most likely refers to 1 John 5:19: "And we know that we are of God, and the whole world [Welt] lieth in wickedness." Kant opens the first part of his Religion within the Boundaries of Mere Reason by referencing the same Biblical quotation. Allen Wood and George di Giovanni's CUP collection of Kant's works on religion misattributes the reference to John's Gospel, rather than to his first Epistle. See RGV 6:18 and Kant (1996a): 457 n. 8.

${ }^{34}$ See DP: $\$ \S 164^{*}, 167,163^{*}$. Wolff's conflict with the Pietist faculty at Halle regarding Pre-Established Harmony and other philosophical/theological issues is often referred to as Pietismusstreit or Causa Wolffiana, for which see Marschke (2015) and Schönfeld (2002).
} 
We shall see later how Wolff resolves these conflicts, and what his general strategy for resolutions of this kind is. At this point, it would be beneficial to refer back to the original thesis of this article. Specifically, I want to claim that the possibility of an occurrence of dogmatic conflicts today, not in the $18^{\text {th }}$ century, presents Guyer's appeal to return to Kant for the purposes of grounding religious toleration with certain difficulties. In order to do this, let us focus on a recent case that could qualify as a case of dogmatic conflict.

On the $13^{\text {th }}$ of November 2019 the Ohio State Legislature House passed the Ohio House Bill 164 entitled "Ohio Student Religious Liberties Act of 2019." 35 Some parts of the bill have raised controversy, specifically Sec. 3320.03 that would prohibit preventing students "from engaging in religious expression in completion of homework, artwork, or other written or oral assignments." The section further states that educational institutions "shall not penalize or reward a student based on the religious content of [their] work." The critics of the bill have argued that this would allow students to answer scientific questions, e.g. about the age of the Earth, or the existence of evolution, in accordance with their religious belief, and the teachers would be forbidden from marking their answer as wrong. The defenders of the bill, on the other hand, have argued that the wording simply provides clarification to teachers on how legally guaranteed rights of free religious expression are to be treated in the classroom. For example, if a student held a religious belief that the Earth is 6,000 years old, they would still be required to provide a scientific answer but could not be penalized for additionally stating that they disagree with it. ${ }^{36}$

Taking the wording of this bill, adopting the interpretation of its critics, and imagining a hypothetical student who would be willing to put down the answer based on their religious conviction (which is also in conflict with the scientific consensus), we can construct a thought-experiment allowing us to evaluate how satisfactorily Guyer's proposal would fare when presented with dogmatic conflicts.

Let us think of a hypothetical student who sees the act of stating that the Earth is 6,000 years old as an essential part of their religious expression. They also refuse to ever state otherwise, even if it would be instrumentally beneficial to them (e.g. for passing an exam), due to an additionally held imperative not to lie. ${ }^{37}$ Under the interpretation proposed by the critics, this student could neither be prevented from nor penalized (through marking) for stating that the Earth is 6,000 years old since that would violate the freedom of their religious expression.

There seems to be something inherently unsatisfactory with this result, as is visible from the fact that the defenders of the bill do not seem to be eager to admit it is a potential consequence. There is nothing strange about being free from state persecution for holding or expressing certain beliefs in conflict with established scientific dogmas. No one should suffer state persecution for believing that the Earth is 6,000 years old, or for shouting it on the street to passers-by. On the other hand, if we consider religious expression as being protected from school examination, some strange consequences follow.

${ }^{35}$ On the $10^{\text {th }}$ of June 2020 the bill was passed by the Ohio Senate and is to be fully effective as of $18^{\text {th }}$ of September 2020.

${ }^{36}$ For this and more details regarding the bill and the surrounding debate, see the article by Valerie Strauss (2019).

${ }^{37}$ Hence they side with Guyer, and pace Mendelssohn, by rejecting, or not seeing as relevant, the 'Protestant conviction' that God does not care about outward compliance with the law. 
For example, let us imagine three different students taking an exam with the question 'How old is the planet Earth'? The first student answers with the scientific dogma: roughly 4.5 billion years. The second student, however, does not know the answer. They decide to put down that the Earth is 6,000 years old, since they have heard someone shouting this in the street, though they do not know why it was shouted. Our third student puts down '6,000 years' as well. Unlike our second student, the third one belongs to a hypothetical Young Earth Creationist group that holds the propositions 'The Earth is 6,000 years old' as a revealed dogma and holds publicly stating it as one of the key principles of their religious expression.

This hypothetical situation seems to present us with a (quasi-)paradox. The first student's answer would be marked as 'correct' since the exam tests the familiarity with the scientific dogma; the second student's answer would be marked 'incorrect', since it conflicts with the dogma and amounts to a wrong guess; the third student's answer, with OHB 164 being in place, would need to be marked as 'correct', or, in some sense, not-wrong. If we compare the answers provided by the second and the third student, we encounter the issue that the identical proposition, 'Planet Earth is 6,000 years old', would be judged as both incorrect and correct (or not-incorrect). Similarly, if we compare the answers of the first and the third student, we find that opposing statements 'The Earth is x years old' and 'It is not the case that the Earth is x years old' are both judged as true, or at least that one of them is true, while its opposite is not-false. This leaves us with several options, such as rejecting the classical logical axiom of bivalence, adopting dialetheism, or providing an account under which the third student's answer can be judged to be wrong, without violating the student's freedom of religious expression.

This raises two questions for Guyer and Kant. The first question is whether Guyer's formulation of the principle of religious liberty would consider penalizing the third student to be a violation of their religious freedom. The second question is whether Kant can provide us with a solution to this type of dogmatic conflict that would not violate his principle of religious liberty as formulated by Guyer.

\section{Guyer, Kant, and the conflict}

What would happen if we looked at this example from Mendelssohn's perspective, i.e. by assuming (i) that inner conviction cannot be modified by the tools available to the state and (ii) that (the Protestant) God only cares about inward convictions? If these two principles formed our ground for religious toleration, what would happen? For Mendelssohn, the state can demand outward compliance, i.e. for our Ohio student to pronounce the age of the Earth to be 4.5 billion years, and is free to penalize non-compliance. However, as Guyer points out, the second pillar is based on the religious dogma that God only cares about inner convictions, and we have already established that for our student God equally cares for outward acts. So Guyer seems right in pointing out that if religious toleration is itself based on a religious dogma, it runs into trouble when dealing with a religion that does not share this dogma. In that case, the question arises what happens when we try to resolve this issue using Kant's principles, which Guyer interprets as follows: 
... any exercise of freedom that is compatible with the like freedom of others must be permitted and indeed defended by the state ... one is free to do anything that does not diminish the freedom of others in a way that one's own freedom is not being diminished. You can believe anything you want, since that does not directly diminish the freedom of others. But you can also say or act in any way you want, before others or to them, in any way that does not directly diminish their freedom. ${ }^{38}$

How does this apply to our situation? The first part of the principle, guaranteeing the freedom to believe or say whatever one wants, does not present any issues in the case of our students. But Guyer's interpretation further states that one can also act in any way that does not diminish the freedom of others. Due to this, it seems that our student's freedom to state on the exam that the Earth is 6,000 years old should not only be allowed, but in fact defended.

This is because it is difficult to see how our student's religious expression hinders the freedom of another. The non-religious students remain free to state their own positions on the age of the Earth. And, while one might say that the tutor's freedom is limited because they cannot perform their duty, i.e. teach the official position in relation to the scientific dogma, we could say that the same complaint could have come from an inquisitor of the state religion who would not be able to penalize people for not behaving in line with the official religious dogmas adopted by the state.

It seems that under Guyer's proposal, our student's right to religious self-expression would be violated by declaring their answer wrong, and hence penalising them, since this could be seen as state intervention targeted against free, non-interfering religious expression compatible with public peace. The strange situation, in which an identical proposition is either true or false based on the ground upon which a student has formed a belief, remains unresolved.

To be fair, however, Guyer's aim is to provide us with the fundamental principle of religious toleration that is not based on religious premises, rather than to present a complete practical system that would resolve all possible issues stemming from the principle as he understands it. Because of this, we should proceed by taking Guyer's interpretation for granted and attempt to find solutions in Kant's writings that might resolve the issue of the conflict as presented here. One place that might be promising to look to is Kant's Conflict of the Faculties.

In the Conflict, Kant addresses the possibility of governmental intervention in teaching. Since, Kant writes, the aim of the government is to find means to secure "the strongest and most lasting influence" on the people, and what the higher faculties (theology, law, medicine) teach are themselves means for securing such an influence, the government reserves the right to sanction what they teach. However, Kant stresses, when the government sanctions something in this way, it does not thereby teach, but only demands that certain dogmas [Lehren], and not others, be disseminated to the public. ${ }^{39}$

\footnotetext{
38 Guyer (2018): 324-325; emphasis in the original.

39 SF 7:19. In fact, Kant states that the government should not even attempt to teach or interfere with the truthfulness of dogmas posited by these faculties.
} 
This means that by declaring the third student's answer to be wrong, the state is not actually directly sanctioning the student, but rather is preventing the tutor from evaluating the question in any other way. The action by the state and the tutor, thereby, does not resolve or even impact the dogmatic conflict between science and religion. After all, according to Kant, it is not the role of the state (and hence institutions that publicly teach dogmas) to attempt to resolve these conflicts in the first place, since this is the job left to the university faculties that operate independently from the state.

But while this might allow us to say that the state is not directly violating the student's religious freedom, the same problems persist as before. While in this case the tutor cannot judge the answer to be correct, since they, as a 'technician of learning', ${ }^{40}$ are required to teach only the dogma of their faculty, not judging it to be correct could still be seen as penalising the student on the basis of the religious content of their work. This is because the student would be put at a disadvantage depending on which dogmas the state has decided to allow to be taught. The same issue would apply if the situation were reversed, i.e. if the state decided that the official dogma to be presented in educational context is the one of Earth being 6,000 rather than 4.5 billion years old. In this case the students who state the latter could also be seen as being put at a disadvantage for expressing the absence of a specific religious belief.

This approach does not seem to deliver the desired solution, since it only pushes the question one step upwards, i.e. from the way a particular dogma is judged, to the question of what should be taught in the context of state education. Due to this, perhaps instead of trying to find a way in which an educational system can resolve dogmatic conflicts without thereby penalising religious expression, we should see whether Kant can show that a genuine conflict does not even occur here.

One way to do this would be to show that religious dogmas are not theoretical propositions at all, but practical ones. For example, in the Conflict Kant argues that, because religious propositions are supposed to be gained from divine revelation, "we cannot give a merely theoretical interpretation of [them] ... we must interpret [them] in a practical way, according to rational concepts." 41 Similarly, "religion is the sum of all our duties regarded as divine commands ... As far as its matter, i.e. object is concerned, religion does not differ in any point from morality." ${ }^{42}$ Additionally, in the first Preface to Religion within the Boundaries of Mere Reason, Kant writes that if something (a concept, proposition, formula) is 'borrowed' by philosophy from religion, this does not mean that

\footnotetext{
${ }^{40}$ See SF 7:18.

41 SF 7:46.

${ }^{42}$ SF 7:36, see also RGV 6:13-14. I am aware that the quotation from the Conflict refers to religion in contrast to ecclesiastical faith and one could argue that our example of dogmatic conflict would be a conflict between philosophy and ecclesiastical faith, rather than philosophy and religion. Since ecclesiastical faith might contain theoretical claims (RGV 7:37, 7:42), the conflict between the two seems to persist. But while it might be more correct to characterise the conflict I have been presenting, as well as Guyer's discussion of religious freedom, as referring to the freedom of and conflict with ecclesiastical faith, I do not think that this matters for my case. This is because Kant states that "ecclesiastical faith, as mere vehicle of religious faith, is mutable and must remain open to gradual purification until it coincides with religious faith" (SF 7:42). This can be interpreted as saying that, as a vehicle for religious faith, ecclesiastical theoretical claims should be seen through their capacity to contribute to practical concerns, rather than theoretical truths.
} 
philosophy "encroaches" into the domain of religion, since whatever is 'borrowed' in this way by philosophy will be used only in the way in which it fits mere reason, and not in the way in which it was used in theology. ${ }^{43}$ Moreover, in the second Preface, he states that while there might be apparent conflicts between philosophy and revealed religion, if we were to look at the relation between the two not from the theoretical, but from "the morally practical point of view ... then we shall be able to say that between reason and Scripture there is, not only compatibility but also unity, so that whoever follows the one (under the guidance of moral concepts) will not fail to come across the other as well." 44

If we were here to understand Kant as suggesting that religious propositions are to be understood practically ${ }^{45}$ rather than theoretically, how does this help our case? Adopting this perspective would result in the elimination of the dogmatic conflict. This is because the proposition 'The Earth is 4.5 billion years old' would count as a theoretical, scientific, proposition, stating the astronomical age of a certain planet. On the other hand, uttering the proposition 'The Earth is 6,000 years old' on the basis of one's religious conviction would amount to stating a moral maxim, e.g. 'one should respect one's elders'.

Under this model, in which we treat religiously grounded propositions as practical, rather than theoretical, we can find a way in which the third student's answer can be judged as incorrect, without violating their freedom of religious expression. The student would not be penalized for expressing their religious convictions, but rather for presenting irrelevant material, i.e. providing a practical proposition where a theoretical proposition is asked for. The practical answer is therefore treated in the same way as if the student left the question field blank, or drew a horse - an action that can be penalised, I hope everyone would agree, without encroaching on that student's rights to free speech or to artistic expression.

This approach appears to me to be genuinely Kantian, as well as to resolve the previously identified issues with the dogmatic conflict. It is also not unheard of to attempt to resolve apparent dogmatic conflicts between the Scripture and science by interpreting the propositions found in the former as allegorical, intended for moral instruction, or in a way that makes them compatible with scientific claims (e.g. by interpreting 'days' in the Book of Genesis as lasting billions of years, rather than 24 hours). However, the Kantian position does require accepting that religious belief itself (rather than just some controversial dogmas) cannot be theoretical, but only practical, which might be a hard point to sell. This is especially the case within the context of grounding religious toleration, since it seems to only recognise those religions which see their dogmas merely as practical instructions as truly being religious. Moreover, by relegating religious dogmas to the sphere of practical reason, we move further away from the possibility of establishing a principle of religious freedom based on the common theoretical standards of truth and evidence. At this point, however, let us end with the Kantian account and see what Wolff's reply might look like.

${ }^{43}$ RGV 6:9-10.

${ }^{44}$ RGV 6:12-13.

${ }^{45}$ Stephen Palmquist (1992) has argued against the claim that Kant reduces religion to morality, however, it seems to me that I here do not propose a reduction of the kind he rejects. I only claim that for Kant religious propositions are to be interpreted as practical propositions, rather than that religion can be "eliminated" or "explained away" by morality. 


\section{Wolff and the conflict}

I have spoken earlier about Wolff's examples of dogmatic conflicts. The important question to ask now is how he solves them. Let us recall some of them. Firstly, Wolff talks about an apparent conflict between Leibniz's philosophical claim that this is the best of all possible worlds, and the claim from 1 John 5:19 that "the whole world lieth in wickedness." This example, however, does not present a genuine, but only an apparent conflict. Wolff argues that a genuine contradiction between propositions cannot arise unless the concepts compared are used in the same sense. In this case, he continues, this does not obtain since by 'world' Leibniz here means "the whole universe of existing things and also the series of things which mutually succeed each other in the universe," while the Scripture uses the term 'world' to designate human race. ${ }^{46}$ Hence, there is no dogmatic conflict here, only mere verbal disagreement.

If we have eliminated the possibility of a mere terminological inconsistency, we additionally ought to check whether the propositions in conflict count as dogmas. Recall that dogmas (in the ideal case) are theoretical propositions that have been demonstrated to be universally true. Hence, it is possible that a certain conflict might not actually be between two dogmas, but between a dogma and a hypothesis. When a conflict arises between a dogma and a hypothesis, Wolff argues, the dogma is not threatened, since a dogma which is supposed to be certain is not challenged by a hypothesis which is by definition uncertain. ${ }^{47}$ The example of this Wolff finds in the theory of the 'Earth in motion', which the Catholic Church maintained as a hypothesis to explain celestial motion, while at the same time holding onto the theological dogma of 'Earth at rest'.

After these two qualifications, we need to ask how Wolff handles the situation in which the conflict between dogmas is genuine, i.e. not a mere verbal conflict, and not a conflict between a dogma and a hypothesis. After all, the Catholic Church no longer believes in Ptolemaic astronomy, hence the theological dogma of 'Earth at rest' must have been abandoned for some reason. Similarly, Wolff puts forward an example of "certain Fathers of the Church [who] once believed that the roundness of the earth is contrary to Sacred Scripture, because they had interpreted certain texts in Scripture as being inconsistent with the roundness of the earth." 48 This brought them into conflict with philosophers who argued for the opposite. According to Wolff, in these cases what was put forth as a religious dogma was not a dogma at all, at least not in the strict sense. For Wolff, the philosophical or natural truth cannot contradict the revealed truth. ${ }^{49}$ In these two cases, the natural truth, discovered by philosophers, only contradicted the erroneous interpretation of the Scripture, which the theologians realised once the natural truth was demonstrated to them clearly enough by the philosophers..$^{50}$

With this in mind, Wolff devotes a chapter to the utility of logic in interpreting the Sacred Scripture both in his earlier German Logic and in the later Latin Logic. In both

\footnotetext{
${ }^{46}$ DP: $§ 158^{*}$.

${ }^{47}$ DP: $\S \S 128,164^{*}$.

48 DP: $\S 163^{*}$.

49 DP: $\S \S 163,168$.

50 DP: $§ 168^{*}$.
} 
versions, he argues that since the Scripture does not immediately communicate the meaning of the words God intended to convey (otherwise there would be no need to translate it from its original languages), the truth of any dogma that is derived from an interpretation of Scripture will need to be demonstrated using the same standard of evidence as any other theoretical dogma. ${ }^{51}$ Moreover, religious dogmas can be divided into the "same classes of truth into which the natural truths are divided and can be examined in the same manner." ${ }^{2}$ Scientific and revealed truths cannot differ qua truths, so in the case that some two propositions that claim to express such truths come into conflict, one of them (or both) must be grounded in an error. Since we can never be sure whether a philosopher or a theologian has committed an error in derivation, any genuine case of such a conflict would require both sides to re-examine their proofs and their interpretations..$^{53}$

Does this mean that there cannot be a genuine case of dogmatic conflict and all of the theoretical religious propositions are simply differently derived theoretical philosophical propositions? In a way, yes, but the answer is somewhat complicated. In the same chapter in which Wolff identifies natural and revealed truth, he also states that "we need be under no apprehension that in this manner faith will be blended with knowledge." ${ }^{54}$ Moreover, while Wolff understands the Sacred Scripture as a book authored by God, and hence holds God to be bound by the same conditions for the good presentation of truths as any scientific author, ${ }^{55}$ he admits that, in the Scripture, God might use some concepts that refer to supernatural things, as well as leave some claims ambiguous, and we should be satisfied that He has done so on purpose. ${ }^{56}$ This leaves it open, at least in principle, that some religious dogmas can come into unresolvable conflict with some philosophical dogmas.

The exact relation between the two can be clarified by looking into Wolff's distinction between 'articuli puri' and 'articuli mixti'. The examples of 'articuli puri' are propositions such as those concerning incarnation, virgin birth, and the Trinity. They are accessible only through revelation and are 'supra rationem'. If something is 'supra rationem', then it cannot be demonstrated through rational principles, but it does not contradict rational principles. ${ }^{57}$ 'Articuli mixti' designate a different class of propositions, the ones that are both disclosed through revelation and accessible to reason. The examples of these will be the propositions treating God as the creator, sustainer, and governor of the world, as well as those treating us as creatures of God. Ultimately, Wolff

\footnotetext{
${ }^{51}$ See DL: c. 12; LL: 2.3.7.

${ }^{52}$ DL: c. $12, \S 8$.

${ }^{53}$ DP: $\$ 167$.

54 "Es ist aber nicht zu besorgen/daß solchergestalt der Glaube mit dem Wissen vermenget wird." DL: c. $12, \S 10$.

${ }^{55}$ DL: c. 12, §4. These conditions are: 1) clear definition of concepts; 2) legitimate premise-conclusion connection between propositions; 3 ) not presupposing anything in subsequent proofs which was not demonstrated in the preceding proof. These three correspond to Wolff's general conception of order and connection, best exemplified by the mathematical method. For this see Theis (2011): 35 .

${ }^{56}$ DL: c. $12, \S \S 6-7$.

${ }^{57}$ See Wolff (1738): §454. Hereafter: TN1. Propositions contradicting rational principles Wolff calls 'contra rationem'.
} 
believes that between the two approaches, theological through revelation and scientific/philosophical/natural through reason there is a 'mirus consensus', guaranteeing that both ways of accessing the truth are ultimately compatible. Due to this, in the case of a disagreement between theological and philosophical propositions, we ought to not simply demonstrate the philosophical truth in question, but also pay attention to how this philosophical dogma fits within the context of revealed theology. ${ }^{58}$

How does all this bear on the dogmatic conflict from our case study? We have set up our student's claim that the Earth is 6,000 years old as a dogmatic, religious claim, i.e. as a theoretical proposition. Both propositions, scientific and religious, use unambiguous terms, referring to the age of a celestial body according to the standard measurement of time. Our situation here is therefore neither the case of a verbal disagreement, nor a disagreement between a dogma and a hypothesis. What we can also see, however, is that the propositions regarding created things are 'articuli mixti', hence they are accessible through both scientific reasoning and religious interpretation of Scripture. In the case of our student, their claim that the Earth is 6,000 years old can and should be penalized since, assuming it has been sufficiently demonstrated that the Earth is older than this, their claim is simply false. As an 'articulus mixtus' nothing changes regarding the truth of this claim whether it comes from religious or scientific conviction. This means that the student's religious freedom would not have been violated, from Wolff's perspective, since their claim regarding the age of the Earth is false, and hence cannot be an expression of a religious truth at all, but simply an expression of their erroneous interpretation of what God has revealed.

\section{Objections to the Wolffian approach}

From the previous section, we can see how Wolff would respond to our case of the dogmatic conflict in comparison to (Guyer's) Kant. If we adopt Guyer's principle of religious freedom without further determinations, our hypothetical student scenario results in an unresolved case of a dogmatic conflict with certain undesirable consequences. This conflict can be subsequently resolved, in a Kantian spirit, by treating religious propositions as practical, rather than theoretical claims. This dispels the conflict and allows us to mark our student's answer as wrong, without violating their religious freedom, but might require taking on board the idea that all religious propositions, no matter how theoretical they might sound, are in fact practical - a position that might not be universally acceptable between different religious groups. While one of Guyer's aims is to formulate the principle of religious liberty that would apply irrespectively of particular religious beliefs, the case of dogmatic conflict suggests that the avoidance of religious premises might not be sufficient for achieving this result.

Looking at the issue from the Wolffian perspective, the situation seems more straightforward. If a religious group were to claim that the theoretical sounding truths that they subscribe to are to be taken in a literal or non-literal sense, there is nothing inherently wrong about either option. All dogmas must ultimately be grasped within a

\footnotetext{
${ }^{58}$ For the discussion of 'articuli' as well as of 'mirus consensus' I am relying on the work by Robert Theis (2011 and 2018), q.v.
} 
coherent overall system. While the dogmas of logic, metaphysics, physics, or theology are different due to the subject matter they cover, ultimately they can all be harmonised in a way which will exemplify no conflict between true, properly demonstrated propositions. There is no inherent reason why religious dogmas would not be theoretical. If a conflict were to arise between religious dogmas and theoretical dogmas derived from a different source, one of the proponents must be mistaken, and their mistake can be demonstrated by approaching the question through the use of the properly conceptualised method of demonstration. ${ }^{59}$ Due to this, penalising our student does not curtail their religious freedom. Since the answer they provide, according to them, comes in a form of a theoretical proposition regarding a celestial object, thereby falling under 'articuli mixti' rather than 'articuli puri', their answer is subject to standards of proof demanded by the science that possesses better claim to truth on the basis of shared standards of correctness. The conflict is resolved without requiring religion to treat its dogmas as practical tout court. If the student, or a religious group, wants to dispute a scientific dogma motivated by their religiously grounded belief, they are free, and even encouraged to do so, as long as they engage with it according to general standards required for demonstrating theoretical propositions. ${ }^{60}$

One potential problem for the Wolffian approach, however, could arise from Guyer's criterion of grounding religious toleration on non-religious premises. In order to guarantee peace in the case of the (apparent) conflict between the proponents of religious and philosophical dogmas, Wolff argues for ideas such as the univocity of natural and revealed truth, 'mirus consensus' between philosophy and Scripture, or God as the author of the world who reveals the secrets of Creation to His creatures. While this might not seem problematic if one is already thinking within the context of Christian theology, this approach might not be applicable to those of different religions, or no religion at all. It seems, therefore, that Wolff, according to Guyer, would be in the same position as Mendelssohn, i.e. his principles for religious toleration would be based on religious premises, albeit different ones.

However, while it is true that Wolff presents his principles of reconciliation between philosophy and theology in these terms, I do not think that we need to see his grounds for reconciliation as religion-dependent. Firstly, we should recall what was said earlier regarding dogmas. They are theoretical propositions demonstrated to be universally true and, more specifically, they are theorems [Lehrsätze]. For Wolff, any proposition is true if there is an agreement between the subject and the predicate of the proposition. Theorems, as discussed in the first section, are theoretical propositions constructed by "placing together several propositions." That means that in the proposition "The Earth is 4.5 billion years old' the definitions of 'Earth', ' 4.5 billion', and 'chronological age'

\footnotetext{
${ }^{59}$ See note 18 above.

${ }^{60}$ This does not seem outrageous to me, since we can find examples of the groups who argue in favour of treating creationism or intelligent design as scientific, rather than religious doctrines, i.e. by arguing that theories such as the spontaneous generation of the universe, or natural selection, are either not demonstrated firmly enough to negate the theistically-inclined theories, or by arguing that there is sufficient religion-independent evidence for the theistically-inclined theories. We might doubt the sincerity or effectiveness of their arguments, but formally speaking, this would constitute a legitimate way of proceeding from the Wolffian perspective.
} 
come together. In the case that there is an 'agreement' between them, the proposition is true. Since religious dogmas are, according to Wolff, equally theorems (since they are not axioms or problems), the conditions of their truthfulness will be the same as for all other theorems. It is true that this will not hold for 'articuli puri', which cannot be demonstrated rationally and follow different criteria for truthfulness, ${ }^{61}$ but any theoretical proposition that is neither 'contra rationem' (i.e. self-contradictory), nor 'supra rationem' (inaccessible to reason, but not irrational), will belong to the rational world ('mundus rationalis') and will be susceptible to the same standards of truth and demonstration as any other. ${ }^{62}$ This means that between 'articuli puri' and philosophical or scientific dogmas a conflict cannot occur, since the latter operate exclusively within the sphere of the rational world. Similarly, if a religious group wants to claim that a certain belief they hold on religious grounds has an impact on how we are to understand theoretical propositions that share the space of intelligibility with the scientific and philosophical ones (if they are 'articuli mixti'), they would need to present them according to the same criteria of truth and demonstration. The peace between the proponents of a religious belief and those who do not share it can therefore be grounded on Wolff's theories regarding the nature of propositions, truth, and demonstration, rather than necessarily requiring any particular religious framework.

The second objection we can raise regards the level of discourse at which I have presented Wolff's solution. The question of religious toleration seems to fall within the domain of ethics, politics, or theology, while I have primarily addressed it from the perspective of Wolff's logic. It is true that Guyer's approach to the question addressed it from a very abstract viewpoint, but at least he addresses the question from the perspective of Kant's practical philosophy (i.e. as a question of freedom), rather than trying to derive it from the Copernican revolution or Kant's theory of the syllogism.

This is a valid objection, but I think addressing Wolff's contribution to this topic from the perspective of his logic is important. Similarly to Kant, Wolff's moral realm belongs within the sphere of the free human action. The moral purpose of our action is the perfection of our and others' capacities resulting in happiness. This perfection refers to the agreement of free human action with the essence and nature of a human being. ${ }^{63}$ The universal rule of free action for Wolff consists in doing what makes one's and others' condition more perfect, and avoiding what makes it less perfect. ${ }^{64}$ This is the law of nature, which governs all human action, and all other laws (the divine law and the human law) must be derived from it. It is validated by nature itself without the need for God, and it would even hold if there were no God. ${ }^{65}$ This being so, it seems that Wolff's moral philosophy fulfils the conditions that Guyer finds promising in Kant's philosophy, i.e. the whole of Wolff's ethics seems to be grounded on religiously neutral principles

\footnotetext{
${ }^{61}$ Although Wolff argues that rationality is still, in some way, inherent in them, and they can be 'disclosed' (patefacit), but not 'established' (efficit) by the scientific method. For this see Theis (2011): 35; Theis (2018): 247.

62 See TN1: $\$ 455$.

${ }^{63}$ Wolff (2010): \$2. Hereafter: DE. For a more detailed account of Wolff's ethics see Schwaiger (2018).

${ }^{64}$ DE: $\$ 12$.

${ }^{65}$ DE: $\S \S 19-20$.
} 
within the context of free human action. However, there are some very significant differences between the two.

As mentioned above, human perfection, which is the goal of moral conduct, is increased if free action results in improving the agreement between a human being and their essence. This means that the fundamental practical principle is ultimately guided by theoretical principles, since one first needs to know what the human essence is in order to act with an intent to increase perfection. While Wolff, similarly to Kant, divides philosophy into theoretical and practical, ${ }^{66}$ practical philosophy is subordinated to theoretical philosophy, since it is subordinated to theoretical cognition. For Wolff, all scientific disciplines, theoretical or practical, depend on metaphysics for their certainty ${ }^{67}$ The important distinction between Kant and Wolff is, therefore, that in Wolff's philosophy we do not find a differentiation in kind between theoretical and practical realm or theoretical and practical truth, with all of human cognition and action being knowable through and subject to theoretical cognition and the philosophical/mathematical method. Because of this, it seems to me that to find a fundamental principle that could ground Wolffian religious toleration, it makes sense to look for it in his logic.

The final issue I would like to address concerns a possibly pernicious side of the Wolffian approach. While his solution might sound simple, it might not be a very attractive one if we are looking for a principle to ground religious toleration today. On the one hand, Kant's position that religion can only provide practical truths might be somewhat difficult to universally accept, but it might be easier than taking on board Wolff's optimism regarding the absolutely univocal and harmonious conception of truth, and the possibility of developing a one-size-fits-all method that would be applicable to all spheres of human learning. Moreover, such conceptions of truth seem to be open to dangerous levels of abuse, with groups that hold power claiming the possession of sufficiently demonstrated dogmas which they have a duty to spread in order to increase the perfection of people who are not in the possession of them. So while potentially successful in solving the little riddle of an Ohio student expressing their religion by claiming that the Earth is 6,000 years old, it seems to be, much more than the Kantian position, open to abuse in order to justify religious persecution, rather than protect from it.

I accept this as a genuine issue and will not pretend to be able to successfully solve it here. It is an issue that recurs with any principle based on positive liberty. One thing that I can point to is the fact that Wolff, himself experiencing prosecution and exile due to his positions, aimed to formulate a system that would maximise 'philosophical freedom', i.e. a situation in which we are permitted to openly state what we think is true or false, and would oppose 'philosophical servitude'.$^{68}$ Philosophical freedom can only be limited if our actions were to endanger public peace, ${ }^{69}$ resonating with Guyer's interpretation of Kant's principle in which freedom can be limited only when it interferes with the freedom of others. Similarly, in his Law of Nations Wolff argues that no nation has

\footnotetext{
${ }^{66}$ See Wolff (2010): 332.

${ }^{67}$ See DP: ch. 3 for Wolff's division of sciences and the 'order and connection' that holds both between them and within particular sciences.

${ }^{68}$ DP: $\S \S 151-153,166$.

${ }^{69}$ DP: $\$ 167$.
} 
the right to "deny another the duties of humanity" on the basis of religious differences, compel another nation by force to adopt its religion, subject another nation on account of religion, or mistreat the missionaries of another religion, since "force is a means not suited to inculcate truth." ${ }^{70}$ Hence, even though I cannot demonstrate that the Wolffian approach to the issue of religious toleration is clearly superior to the Kantian one, or that every issue that it might raise can be sufficiently addressed, it still seems to me to be a legitimate, though neglected, approach one can take towards the questions regarding religious toleration, and deserves to be investigated to a greater extent.

\section{Conclusion}

Guyer starts his article by claiming that the freedom to follow or not follow any religion is under attack in the West. If this is right, I wonder whether it is because, as he suggests, we lack a principle that would save us from suffering such an attack, or whether it is because we lack common standards of truth that we can levy against those who are undertaking this attack. While the Kantian approach can be utilised to provide us with the former, Wolffian approach can be developed to provide us with the latter.

My intention here was to present the Wolffian approach as an alternative model from the same period of the history of philosophy. While this model is not without its drawbacks, I believe it presents us with an opportunity to consider grounding religious freedom in a way that shares the positive aspects of what Guyer identifies in Kant, while addressing the issue form the perspective of theoretical reason and positive liberty.

\section{References}

Beiser F.C. (1987), The Fate of Reason: German Philosophy from Kant to Fichte, Harvard University Press, Cambridge MA.

Corr C.A. (1966), Order and Method in Christian Wolff's Philosophy, Saint Louis University, Saint Louis MO.

Frketich E. (2019), “Wolff and Kant on the Mathematical Method," Kant-Studien 110 (3): 333-356.

Gava G. (2018), "Kant, Wolff, and the Method of Philosophy," [in:] Oxford Studies in Early Modern Philosophy, Volume VIII, D. Garber, D. Rutherford (eds.), Oxford University Press, Oxford: 271-304.

Gómez-Tutor J.I. (2018), "Philosophiebegriff und Methode," [in:] Handbuch Christian Wolff, R. Theis, A. Aichele (eds.), Springer VS, Wiesbaden: 73-92.

Guyer P. (2018), "Mendelssohn, Kant, and Religious Liberty," Kant-Studien 109 (2): 309-328. Kant I. (1793/1996a), Religion within the Boundaries of Mere Reason, trans. A.W. Wood, G. di Giovanni, [in:] I. Kant, Religion and Rational Theology, Cambridge University Press, New York: 39-215.

Kant I. (1798/1996b), The Conflict of the Faculties, trans. M.J. Gregor, R. Anchor, [in:] I. Kant, Religion and Rational Theology, Cambridge University Press, New York: 233-327.

Kant I. (2007), Critique of Pure Reason, trans. N. Kemp Smith, Palgrave Macmillan, Basingstoke.

${ }^{70}$ Wolff (2017): §§259-263. 
Marschke B. (2015), "Pietism and Politics in Prussia and Beyond," [in:] A Companion to German Pietism, 1660-1800, D. Shantz (ed.), Brill, Leiden: 472-526.

McCaskill N.D. (2016), "Sabàto, after RNC speech, says Obama 'absolutely' a Muslim," Politico, 18 July, URL = https://www.politico.com/story/2016/07/antonio-sabato-obama-muslim-225788 [Accessed: 31.07.2020].

Palmquist S. (1992), “Does Kant Reduce Religion to Morality?,” Kant-Studien 83 (2): 129-148.

Schönfeld M. (2002), “German Philosophy after Leibniz," [in:] A Companion to Early Modern Philosophy, S. Nadler (ed.), Blackwell Publishing: 545-561.

Schwaiger R. (2018), “Ethik," [in:] Handbuch Christian Wolff, R. Theis, A. Aichele (eds.), Springer VS, Wiesbaden: 253-268.

Strauss V. (2019), “Does the Bill Just Passed by the Ohio House Allow Students to Be Wrong in Science Class without Penalty if They Cite Religious Reasons?," The Washington Post, 16 November, URL = https:/ / www.washingtonpost.com/education/2019/11/15/ does-bill-just-passed-by-ohio-house-allow-students-be-wrong-science-class-without-penalty-if-they-cite-religious-reasons/ [Accessed: 05.02.2020].

Theis R. (2011), “'Ut \& scias, \& credas, quae simul sciri \& credi possunt': Aspekte der Wolffschen Theologie," Aufklärung 23: 17-39.

Theis R. (2018), “Theologie," [in:] Handbuch Christian Wolff, R. Theis, A. Aichele (eds.), Springer VS, Wiesbaden: 219-250.

Wolff C. (1713), Vernünfftige Gedancken von den Kräfften des menschlichen Verstandes und ihrem richtigen Gebrauche in Erkäntniß der Wahrheit, Rengerische Buchhandlung, Halle.

Wolff C. (1735), Philosophia rationalis sive Logica, methodo scientifica pertractata, Dionysius Ramanzini, Verona.

Wolff C. (1738), Theologia naturalis, methodo scientifica pertractata. Pars prior, Dionysius Ramanzini, Verona.

Wolff C. (1963), Preliminary Discourse on Philosophy in General, trans. R.J. Blackwell, The Bobbs-Merrill Company, Inc., Indianapolis.

Wolff C. (1733/2010), Reasonable Thoughts About the Actions of Men, for the Promotion of Their Happiness, trans. J.B. Schneewind, [in:] Moral Philosophy from Montaigne to Kant, J.B. Schneewind (ed.), Cambridge University Press, Cambridge, 331-350.

Wolff C. (2017), The Law of Nations Treated According to the Scientific Method, trans. J.H. Drake, Liberty Fund, Inc., Carmel IN. 